\title{
Competitiveness and Resilience of the productive districts in Sicily. The behavior of the Sicilian production areas during the economic crisis
}

\author{
Michele Sabatino'
}

ABSTRACT

KEY WORDS: resilience, productive district, regional strategy, economic crisis

"Resilience" refers to the ability of companies to adapt their strategies in response to economic circumstances that change from time to time. This definition seems appropriate to explain the behavior of the Sicilian productive districts in light of the recent economic crisis. These meta-producing districts of Sicily merit further study, particularly in terms of the concept of resilience and its accompanying economic dynamics. The Sicilian Region has recognized these productive districts, which represent an attempt to use industrial policy to promote various types of mergers among companies. This regional strategy could have been a useful tool to induce the production system to direct its decisions toward forms of integration and inter-company collaboration that would also strengthen the previously begun processes of local development. The crisis reduced any regional policy aspirations and above all decimated the numerous small enterprises that might have represented the backbone of the proto-districts. After an initial methodological and historical reconstruction, the present study focuses on the Sicilian production areas - with particular reference to the industrial area - from the first years of their establishment and regional recognition to those latter years marked by the economic crisis. Thus, we evaluate the degree of resilience of the different districts and their competitive capacities. Arguing about competitiveness and resilience means, on one hand, to understand what the factors are that combine to reduce the vulnerability of a territory and a production system and on the other hand, to identify strategies to increase financing for the same factors that are crucial to a region's economic growth.

JEL Classification: $\quad$ O1, O25

${ }^{1}$ KORE University of Enna, Italy

\section{Introduction}

The current international financial crisis has severely affected Italy and its economy. The austerity policies that are required - which involve reducing

\section{-}

Correspondence concerning this article should be addressed to: Michele Sabatino, KORE University of Enna, Via Donna nuova 109 - 94100 Enna, Italy. Tel - fax +39.0935.22599, Email: michele. sabatino@unikore.it the public debt - have also made it more difficult to develop local economies, particularly lagging economies such as Sicily's.

The manufacturing districts promoted by the Sicilian Region are the main subject of this paper and appear to be a reality in motion for almost ten years; as such, they can help promote local development in this particularly difficult economic context. At the end of the past decade, recognizing the productive districts 
promoted by the Sicilian Region represented the industrial policy's attempt at promoting types of mergers between companies inside a regional context; in this context, applying the latest methods to mapping the Italian districts (Sforzi, 2009) left the entire island unguarded, although these embryonic forms of protodistricts or districts were already present.

The economic crisis and de-industrialization processes underway in Italy and Sicily seem not only to have set aside any aspirations of regional industrial policy but also to have decimated the universe of micro and small enterprises that might represent the backbone of the recognized proto-districts.

In the most recent economic literature, the term resilience refers to the ability of companies to adapt their strategies in response to changes in economic situations that arise from time to time (Christopherson, Michie, \& Tyler, 2010). This definition seems particularly suited to explaining the behavior of the Sicilian productive districts in light of the recent economic and financial crises. Beginning from this concept (which is now widespread in the economy) and linking it to the historical and socio-economic dynamics of the Sicilian context, the meta-districts of Sicily are certainly an interesting case study.

This paper aims to assess the degree of resilience of the various Sicilian districts with particular reference to the group of companies participating in the districts recognized by the Sicilian Region. Therefore, this research intends to illuminate how the member companies of districts respond to the effects of the economic crisis and whether joining the district strengthens their resilience. In particular, following a methodological and historical reconstruction, we focus on the Sicilian production areas - with particular reference to those classified as industrial - beginning from the first years in which the Region was recognized until the recent economic and social crisis. Thus, we will evaluate the different Sicilian districts' resilience and their competitive capacity with a specific focus on the leading enterprises of the districts and the leadership role they exercised during the economic crisis. We see that speaking of competitiveness and resilience means, on one hand, understanding what the factors are that have combined to reduce the vulnerability of a territory and a production system, and on the other, identifying strategies that increase the financing of the same factors that economic theory indicates are crucial to a region's economic growth.

\section{Theoretical framework}

The literature on industrial and productive districts is now quite extensive and filled with definitions. However, industrial districts represent a heterogeneous set with regard both to their social base and their production structure, which is particularly evident in a country such as Italy in which this particular form of spatial organization of production is more prevalent than in other countries (Berardi \& Iannuzzi, 2012; Paniccia, 1998). Nevertheless, industrial districts have clearly identifiable common features as follows: they are limited areas, and each has a population of manufacturing and services that share business areas that are variously specialized and interconnected (Camuffo \& Grandinetti, 2011). In the industrial districts, institutional subjects that support the district's development are at work (Provasi, 2002).

As defined above, the industrial districts do not appear to differ in any way from the clusters defined by Michael Porter (1998) as follows: geographic concentrations of interconnected companies and institutions sharing a particular field of activity. In fact, there is a difference, and it is not insignificant; Porter (1998) makes no reference to the extension of spatial clusters, and there are, therefore, many clusters among his examples that cover the territory of an entire differentiated state, such as the clusters of vine-wine in California, the furniture cluster in North Carolina or the forest products clusters in Sweden (Porter, 1998). Inside the clusters, the concentration process is essentially generated by economic circumstances and the main reference is the enterprise and related industry sector. By all appearances, these production systems are not comparable with traditional Italian industrial districts, which are generally limited to a few and generally small municipalities with an organizational model defined using the local community in which the business population works. In addition, an industrial district is the product of a bottom-up process that involves both the local community and the companies operating in the same territory, and it also requires the presence of a system of standards and shared values and a common level of trust between local actors 

production, the heightened competition increasingly based on innovation and, in particular, to the industrial application of knowledge. Theoretical and empirical studies from a number of scholars such as, for example, Rullani (2004; 2009), Fortis and Quadrio (2006), Corò and Micelli (2006) have shown that the development of these districts is today related to the development of the knowledge economy, which depends mainly on research, innovation, high-quality human capital, available and efficient "networks" and positive interactions with institutional actors.

In the modern scientific literature, the first criterion for identifying meta-districts is multi-sectoral - not only as a significant link in the supply chain within the areas identified but also as a significant number of services to enterprises (for example, research and experimentation services). The second criterion involves territoriality because if the concept of meta-districts attempts to overcome old ties to create new ones based on new technologies and services necessary for enterprises' competitiveness, it is also true that everything is based on a form of confidence that must give thanks to a relationship of "proximity". Moreover, the new information and communication technologies are not absent from all businesses in the territory. The third criterion involves leadership. In identifying a metadistrict, it is essential to ensure the presence of one or more business leaders who can represent the sector and act as a "drag". The final criterion requires that the institutional environment must play a significant role in overcoming barriers related to enterprises' conflicting positions. Based on these elements, the eligible areas within which the presence of district characteristics (strong horizontal structure, a high percentage of outsourcing, close relations of subcontracting, high dissemination of knowledge, etc.) are identified that can enable the modern structures of the "metadistricts" to be achieved.

In contrast to the existing business reality, it seems clear that the Sicilian Region's proposed industrial districts have more in common with the experience of clusters proposed by Michael Porter (or even networks of companies), which makes it easier to identify them in their first application in Sicily. There is in fact no doubt that the efforts of the Sicilian Region to adopt an "industrial" policy and then a legislative instrument to contribute to the creation and subsequent development of hypothetical districts in Sicily is certainly positive but discounts the objective limitation that districts are not created by legislation but are instead also the result of evolutionary processes involving economic, social and cultural (and other) institutions, in addition to the major role played by the regulatory framework (Rullani, 2009; Schilirò, 2010b; Viesti, 2000). We can at most speak of a regulatory model that the various production areas should or could adapt in time.

In line with what has previously been said, Signorini (2000) argued - in referring to the problem of the "creation" of the productive districts by decree - that, in general, districts have sprung up spontaneously and often almost unexpectedly in the evolution of a local artisan tradition to facilitate the maturation of embryonic entrepreneurial skills, to thicken subcontracting relationships, and sometimes in response to the various crises of large local businesses. Furthermore, the birth of the districts is also linked to the development of new businesses and to the beginnings of new productions that aim to compete in the markets and not to "capture" incentives. It is, therefore, difficult to find elements that favor the birth of a district by decree or administrative measures. Thus, a legislative framework, even if useful and properly oriented, cannot constitute a sufficient condition for creating these districts.

Nevertheless, the experience of industrial districts seems, at least, to have played an initial aggregating and supporting role in the Sicilian production system, which perhaps might be even better accompanied and supported in light of recent economic crises. It is significant that the data that from the euphoria of the first application of 23 districts recognized that only 19 remained due to turnover of inputs and lack of rewards.

Following this path in law and practice of industrial clusters and their evolution, the definition of "resilience" seems particularly suited to explain the behavior of the Sicilian productive districts in light of recent economic crises. In the most recent economic literature, the term resilience indeed means the ability of companies and/or regions to adapt their strategies in response to changing economic circumstances that arise from time to time (Christopherson et al., 2010).

More generally, those economic and productive systems affected by shocks may show - over the short or medium term - the following different reactions: a) 

in contrast to the general data from Sicily, if and how companies participating in the district have benefited from greater resilience than non-participating companies and, finally, whether the leading companies embodied an attractive feature separating it from other companies in the district.

\section{Results}

In planning for the implementation of cohesion policy in Sicily, the Sicilian Region has identified the industrial district as a new tool for territorial governance. This choice is related not only to law $140 / 1999$ but also to (financial) law 266/2005 (art. 367-372), since it introduced the legal concept of "productive district" that became a subject with independent legal status.

Regional law 17 December 2004 set up the manufacturing districts. In art. 56, the law states that the Department of Regional Cooperation, Trade, Craft and Fisheries would adopt (by decree) the criteria for recognition of the productive districts, which are interpreted as clusters, such that the same clusters could assume the role of referees for the programming policies and development of the region and, therefore, act as final beneficiaries of EU, state or regional funds. On 1 December 2005, the Department of Regional Cooperation issued a Decree (DA)152 establishing the criteria for identifying and recognizing the procedures for manufacturing districts, and the arrangements for implementing interventions under the Pact of Development District, regulated by art. 5 of the same decree. In particular, art. 2 of the decree defines industrial districts as "industrial clusters characterized by the presence of clusters that carry out similar activities according to a logic of supply chain, vertical or horizontal, and also a set of institutional actors with responsibility and operating in the activity of supporting the local economy". According to regional rules, districts must consist of a cluster of companies engaged in similar activities and having a set of institutional actors (universities, research institutes and higher education, government, etc.). They must present themselves as a horizontal or vertical industry, along with transnational dislocations (i.e., able to guarantee localization and competitive advantages). Moreover, they must have more than 50 enterprises with at least 150 employees; there must be a high degree of integration among these companies (to be documented with supply chains) and there must be a high capacity for technological innovation (production processes, leading companies, educational institutions, etc.). A level of technological innovation is also required, which is proven by their production and/or the presence of leading companies in each sector, as well as by the presence of educational institutions and/ or specific documentation centers regarding the local culture of product and labor.

In Sicily, before the Sicily Region Decree recognized the productive districts, ISTAT recognized the presence of only the following two industrial manufacturing districts or SSLs on the island in its 2001 census: the district of Custonaci (TP), within the goods for home sector with 532 companies and 1.355 employees, on one hand, and the District of Sinagra (ME), operating in the textile and apparel sector with 284 companies and 643 employees, on the other. Simultaneously, they identified some areas that with local production systems, such as the ceramics of Caltagirone (CT), the Sea Fisheries District of Mazara del Vallo (TP), the food vegetable District of Pachino (SR), and the technological District "Etna Valley" (CT).

The conclusion of the formal creation of productive districts in Sicily is accomplished by decree 546/12s of 16 March 2007 in which financing 23 industrial clusters is recognized and accepted. Table 1 shows the 23 productive districts recognized by the Region by province and sector.

An analysis of Table 1 and the location of the members of any individual districts shows, first, that the Sicilian Region has favored a territorial demarcation and aggregation rather than sectorial and/or specialized production in attempting to enforce an indicator of continuity between enterprises, except for some cases such as the Red Orange, in which the territorial aggregation, which involves mainly the provinces of Catania and (to a lesser extent) Syracuse, coincides with that of specialization. There are also cases of redundant duplication in areas such as ceramics, wine, recreational boating and (in part) fishing.

The disproportionate number of productive districts recognized that there are 3.448 companies with approximately 43.500 employees, which considers that the National Observatory of the Districts recognizes in its annual report (2014) just 4 districts (fishing, textiles, mechanical and mechatronics). Considering also that in other regions, i.e., "in districts" in Europe such as 
Table 1. District production recognized by the Region of Sicily (2007) by province and sector.

\begin{tabular}{|c|c|}
\hline Productive districts & Type \\
\hline Blood Orange (CT) & Agriculture \\
\hline Ceramics of Caltagirone (CT) & Industrial Craft - Ceramics \\
\hline Unique Regional Cereals - SWB (EN) & Food Industry \\
\hline Sicily Eastern Textile Chain (CT) & Industry - Textiles \\
\hline Sicilian Table Grape - PGI Mazzarone (CT) & Agriculture-Viticoltura \\
\hline Logistics (PA) & Industry - Logistics \\
\hline Mechatronics (PA) & Industry - Mechatronics \\
\hline Nautica Due Mari (ME) & Industry - Nautica \\
\hline Fishing and Fishing Tourism Siciliae (TP) & Fishing and Tourism \\
\hline Plastic (SR) & Industry - Chemistry \\
\hline Fruit and vegetable quality of the Val di Noto (SR) & Agriculture \\
\hline Sicilian wine (PA) & Agriculture -Viticoltura \\
\hline Sicilian ceramics (ME) & Industrial Craft - Ceramics \\
\hline Industrial fishing COSVAP (TP) & Fishing \\
\hline Etna Valley (CT) & Industry-HiTech \\
\hline Florovivaismo Siciliano (ME) & Agriculture -Floricoltura \\
\hline Stone Materials Outstanding (TP) & Industrial Craft \\
\hline \multicolumn{2}{|l|}{ Mechanical (SR) Industry - Mechanics } \\
\hline Pleasure Craft (PA) & IndustryNautica \\
\hline Horticultural South East Sicily (RG) & Agriculture \\
\hline Lava Stone (CT) & Industrial Craft \\
\hline Olive lands of the West Sicily (TP) & Agriculture \\
\hline Wine in Western Sicily (TP) & Agriculture -Viticoltura \\
\hline
\end{tabular}

Source: Observatory of Industrial Clusters and SMEs, Sicily (2014)

Veneto, by Census data from ISTAT 2001, there are 22 districts in which 37.784 "Local Manufacturing Units" are operating, there is clearly an inconsistency in the duplication of manufacturing districts in areas that are almost identical and there is a clear fabric weakness in the Sicilian production in comparison with that of the more industrialized regions. This proliferation is neither an expression of dimensional efficiency nor specialization but is instead inspired by other mechanisms related to searching for public funding or political logic and belonging. The large number of districts is unjustified based on the productive dimensions of the entities and their strength in the various markets. Finally, the large number of production areas does not take into account (if not negligible at the moment that partners are identified at the district formation) external economies, i.e., that factor in what the basic economic logic of the companies was when they formed themselves into districts.

Over the years, the Sicilian Region has both recognized additional production areas and confirmed those previously recognized with the first Decree of 
Table 2. Productive Districts recognized by the Region of Sicily from 2011 to 2013

\begin{tabular}{ll}
\hline Productive districts & Type \\
\hline Poultry (RG) & Agriculture \\
Orange of Ribera (AG) & Agriculture \\
Eda - Eco Domus (AG) & Industry - Construction \\
The beef food chain (PA) & Agriculture \\
Ficodindia Calatino South Simeto (CT) & Agriculture \\
Dairy (RG) & Agriculture \\
Sicilian Sweet (PA) & Agriculture \\
Wood and Furnishings (CT) & Craftsmanship \\
Aluminum and Related Areas (RG) & Industry - Mechanics \\
Nautica (PA) & Arts - Tourism \\
Wellness Spa (ME) & Tourism - Health \\
\hline
\end{tabular}

Source: Observatory of Industrial Clusters and SMEs, Sicily (2014)

Table 3. District production recognized by the Region of Sicily (2014) by province and sector.

\begin{tabular}{|c|c|}
\hline Productive districts & Type \\
\hline Blood Orange (CT) & Agriculture \\
\hline Unique Regional Cereals - SWB (EN) & Industry - Food \\
\hline Mechatronics (PA) & Industry - Mechatronics \\
\hline Beef Food Chain (PA) & Agriculture \\
\hline Industrial Fishing COSVAP (TP) & Fishing \\
\hline Etna Valley Catania (CT) & Industry - Hi Tech \\
\hline Sicilian Florivivalismo (ME) & Agriculture -Floriculture \\
\hline Outstanding Stone Materials (TP) & Industrial Craft \\
\hline Mechanics (SR) & Industry - Mechanical \\
\hline Lava Stone $(\mathrm{CT})$ & Industrial Craft \\
\hline Poultry (RG) & Agriculture \\
\hline Eda - Ecodomus (AG) & Industria - Construction \\
\hline Calatino Ficodindia South Simeto (CT) & Agriculture \\
\hline Dairy (RG) & Agriculture \\
\hline Sciliano Sweet (PA) & Agriculture \\
\hline Wood and Furnishings (CT) & Craftsmanship \\
\hline Aluminium and related areas (RG) & Industry - Mechanics \\
\hline Nautica (PA) & Arts - Tourism \\
\hline Wellness SPA (ME) & Tourism - Health \\
\hline
\end{tabular}

Source: Observatory of Industrial Clusters and SMEs, Sicily (2014) 


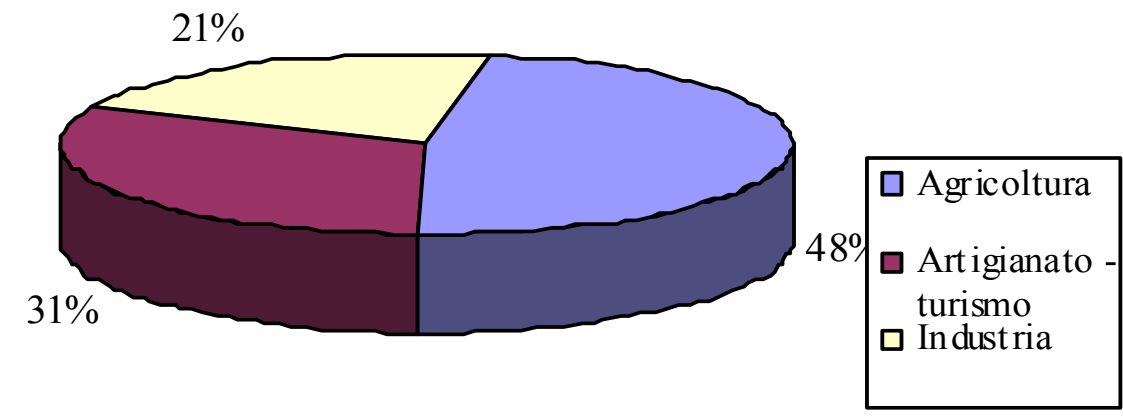

Figure 1. Clusters Sicilian Breakdown by sector.

Source: Authors` own elaboration on the basis of Observatory of Industrial Clusters and SMEs, Sicily (2014)

2007. Decree 611 of 2011 recognized the other 7 (seven) manufacturing districts, and Decree 744 / gab 2012 recognized the Beef Food Chain District, whereas Decree 184/2013 recognized 3 (three) additional districts. Table 2 shows the 10 new productive districts recognized by the Region of Sicily in provinces and sectors from 2011 to 2013.

In recent years, as required by Decree No. 152 in 2005, the Regional Department for Industry verified the existence of indicators of relevance, confirming only 19 industrial clusters. Table 3 shows the 19 productive districts recognized by the Region of Sicily by province and sector up to 2014 .

The division of districts by sector, which is depicted in Figure 1 and derived from Table 3, is as follows: Agriculture and Fishing comprise the largest share, at $47 \%$ and 9 manufacturing districts, closely followed by Handcrafts and Tourism with a share of 32\% with 6 districts and finally the industry with four productive districts with $21 \%$, confirming that the for economic impact of Sicily Agriculture remains important.

Ultimately, there are 10 (ten) productive districts (PD) of industry and crafts recognized by the Sicilian Region. Among these, there are 4 districts in industries excluding construction as follows: Etna Valley (CT), Mechanics (SR), Mechatronics (PA), aluminum (PA). The remaining six districts of production come from crafts, industry or tourism and are as follows: Eda Ecodomus (AG), wood and furnishings (CT), Lapidei Outstanding (PA), Lava Stone (CT) and finally the Wellness Spa (ME). However, Table 4 shows the number of companies involved in each industrial cluster and their territorial distribution by province. A total of 19 companies involved in the production areas at the time of their recognition was $1.958 \mathrm{com}$ panies, and the number of people employed at that time amounted to 20.980 .

The 10 manufacturing industry, trade and tourism Districts that include 826 companies, some of which are manufacturing companies, service companies and others that engage in marketing the products from the manufacturing districts. In 2015, there were 14,619 employees in the 10 industrial and handicraft districts. It was not included because we consider that number of employees in the Mechanics District.

Since 2008, the ERDF (European Fund for Regional Development) has funded (DDG 2970 del22 / 10/2008) grants, i.e., projects submitted by some of the 23 productive districts recognized in 2007. In particular, the ERDF has financed 12 projects submitted by 11 districts (Productive District Etna Valley has presented two projects, both of which were co-financed) by committing funds equaling a total of $€ 3.956,400$. However, the results have not been satisfactory. Thus, in December 
Table 4. District production in Sicily: Number of companies, employees and distribution by province (2014)

\begin{tabular}{|c|c|c|c|c|c|c|c|c|c|c|c|}
\hline Productive Districts & TP & PA & ME & AG & $\mathrm{CL}$ & EN & $\mathrm{CT}$ & RG & SR & Tot & N. Employees \\
\hline Blood Orange (CT) & & 2 & 2 & 27 & & & 54 & & 19 & 104 & 2.033 \\
\hline Unique Regional Cereals- SWB (EN) & 1 & 1 & 1 & & 1 & 20 & 26 & & 3 & 53 & 184 \\
\hline Mechatronics (PA) & 20 & 63 & 3 & 4 & 4 & & 4 & 4 & 1 & 103 & 2.080 \\
\hline Beef Food Chain (PA) & & 88 & & & & 30 & & & & 118 & 162 \\
\hline Industriale Fishing COSVAP (TP) & 85 & 5 & & 10 & 1 & & 2 & & 1 & 104 & 1.092 \\
\hline Etna Valley Catania (CT) & & 4 & 5 & & & 1 & 68 & 4 & 2 & 84 & 5.111 \\
\hline Sicilian Florivivalism (ME) & 1 & & 75 & & 1 & & 13 & 1 & & 91 & n.d. \\
\hline Outstanding Stone Materials (TP) & 44 & 5 & 1 & & & & & 12 & & 62 & 717 \\
\hline Mechanics (SR) & & & & & 1 & & 1 & & 60 & 62 & n.d. \\
\hline Lava Stone $(C T)$ & & & & & & & 50 & 1 & & 51 & 536 \\
\hline Poultry (RG) & 1 & & & & & & 2 & 52 & 6 & 61 & 436 \\
\hline Eda - Eco domus (AG) & 3 & 3 & & 139 & 3 & & 2 & & 1 & 151 & 1.711 \\
\hline Calatino Ficodindia South Simeto (CT) & & & & & 25 & 18 & 12 & & & 55 & 260 \\
\hline Dairy (RG) & 11 & 113 & & 2 & 8 & & & 118 & & 252 & 960 \\
\hline Siciliano Sweet (PA) & & 42 & 45 & 48 & & 17 & 83 & 25 & 34 & 294 & 1.234 \\
\hline Wood and Furnishings (CT) & & & & & & & 51 & & & 51 & 356 \\
\hline Aluminium and Related Areas (RG) & & & & & & 2 & 25 & 97 & 17 & 141 & 1.239 \\
\hline Nautica (PA) & 5 & 50 & 7 & 1 & & & 4 & 3 & & 70 & 317 \\
\hline Wellness SPA (ME) & 5 & 4 & 21 & 8 & & & 13 & & & 51 & 2.552 \\
\hline Total & 176 & 389 & 160 & 239 & 44 & 88 & 410 & 317 & 144 & 1.958 & 20.980 \\
\hline
\end{tabular}

Source: National Observatory of Italian Districts (2014)

2009, although the Region of Sicily issued a second call concerning the development plans of the supply chain within the ERDF OP 2007/2013 that applied to only 10 Industrial Clusters, it was notable that the undertakings, and in particular the districts recognized by the Region, were not always able to show those investments in design skills and the know-how to incentivize and use it effectively and efficiently.

The results of the empirical analysis refer to four (4) clusters of industry that include Etna Valley (CT), Mechanics (SR), Mechatronics (PA), and Aluminium (PA). Until 2014, there were of 390 companies involved, which employed 11.884 persons. In 2007, the year the productive districts were recognized by the Region, there were 13,447 employees in the three industrial districts (the
District of Aluminium had not yet been entered or recognized). These are pre-crisis data, and the employment situation has changed dramatically from 2009 to 2013 as a result of corporate restructuring.

We now consider each of the four districts beginning with Etna Valley Productive district of Catania, which is the most important industry in terms of size, number of employees, turnover, etc. The district Etna Valley is a well-defined technological industry, and its components are bound to one another through a production chain, with dislocations in a vast area of over territorial constraints, through (long) networks of associated companies linked through technological, organizational and functional bases. The business system of the Etna Valley Productive district is characterized by a vertical 
Table 5. Industrial districts in Sicily: Number of member companies and employees

\begin{tabular}{|c|c|c|c|c|}
\hline \multirow[t]{2}{*}{ Distretti produttivi } & \multicolumn{2}{|c|}{2007} & \multicolumn{2}{|c|}{2014} \\
\hline & Tot & Employees & Tot & Employees \\
\hline Mechatronics (PA)* & 94 & 2.080 & 103 & 2.080 \\
\hline Etna Valley Catania (CT) & 136 & 7.916 & 84 & 5.111 \\
\hline Mechanics (SR) & 94 & 3.454 & 62 & 3.454 \\
\hline Aluminium and Related Areas (RG) & / & / & 141 & 1.239 \\
\hline Total & 324 & 13.447 & 390 & 11.884 \\
\hline
\end{tabular}

* The data of employees are unchanged because the company has employees over the region

** District of Aluminium was recognized in 2014

Source: Observatory Industrial Clusters and SMEs, Sicily (2014)

or horizontal productive chain in the high-tech sector; it included 136 companies operating in the areas of manufacturing and high and medium technology services, with a high density of entrepreneurial enterprises, in some cases, of specialization systems integrated as consortia. The technological center of Etna Valley, which gave birth to the development of the Pact Etna Valley Production District, is the result of a partnership between ST Microeletronics and the University of Catania. The Etna Valley district had approximately 7.916 employees, most of whom are in industries mainly consisting of small businesses and over 3.000 in Microeletronics ST. Today 84 companies are participating in the district, featuring over 5.000 employees. Production revolves around silicon and from this product, the companies of the district have developed many products that are necessary to several production systems in various hi-tech industries. The district is also characterized by a high degree of openness and internationalization, as many of the companies participating in the district are well-positioned in foreign markets. Although the recent economic crisis has reduced both the numbers of companies and numbers of employees, we can certainly say that the Etna Valley district is close to the model of a meta-district that could be organized around a market leader because of its characteristics, including its strong commitment to innovation, its business-university linkages, and its multi-sectorial nature. Finally, the district is active in presenting projects and in obtaining both public and private financing.
The second-ranking Sicilian Productive District in terms of enterprises and employees and in terms of turnover and that also focuses on innovation in the hi-tech sector is the Mechatronics Pin Palermo, which consists of 103 employees compared to 94 at the time of recognition, resulting in a total of 2.080 employees within the entire production chain. The district is characterized by industrial companies performing important functions in the engineering industry, and it also has a presence in the business services sector and ICT, although its manufacturing base consists mainly of micro-enterprises that are unbalanced in traditional sectors. The Mechatronics District not only is represented by companies in the province of Palermo $(63 \%)$ but also includes companies belonging to the following other provinces in the region: $\mathrm{Cal}-$ tanissetta, Trapani, Catania, Agrigento, Ragusa. The district was promoted by Confindustria Palermo and, together with the University, was born to enhance a highly technological border area, which ranks it highly among the mechanics, auto, electronics and computer science fields. There is a leading enterprise such as Engineering Ingegneria Informatica $\mathrm{SpA}$ in the field of business integration, application outsourcing and infrastructure, and innovative solutions and strategic consulting. Within the manufacturing branch, particularly in Palermo province, the most representative product categories include the following: production of non-ferrous and semi-finished metals, steel casting and, above all, the manufacture of motor vehicles, con- 
struction of railway rolling stock and wooden vehicle parts. There is also a significant presence of small and highly competitive firms, thanks to their specialization in particular products such as, for example, components for the automotive sector. Although this district is still oriented toward the meta-model district and is active in presenting projects in the region.

The third district is the Mechanics Productive district in Syracuse, which is populated by 62 companies. It is characterized by the presence of some leading companies such as SudProgetti IREM Spa and Spa. Their statistics are not in our possession, and the updated data on employment we consider arbitrarily confirmed. The 2007 data of 3.454 units are found on the official website but with 116 member companies, which compares inexactly to the 94 members in the Sicilian Region. This DP consists largely of companies that produce or are responsible for the maintenance of industrial plants. Moreover, in this PD, there are a good number of companies that provide services to businesses. Although not particularly oriented to innovation, this district has some characteristics similar to the meta-district model (enterprise leaders and multi-sectoral approach). The DP of mechanics has remained active in presenting projects and obtaining funding from the Region.

The last recently recognized manufacturing district is the Productive District of Aluminium and related fields. The District has 141 companies and various institutions and economic and social representatives, with a turnover of approximately EUR 150 million and 1.239 occupied units directly in the field. The District of Aluminium and related fields has its core in Ragusa province, where most of the companies that underwrote the Development Compact District are concentrated, although there are also companies in Siracusa, Catania and Enna provinces. The company that plays a leading role in the District is the Metra Ragusa Spa. The production process of the District has a strong vertical and horizontal integration, with a specific concentration of production in the Ragusa province, in which there is a leader at the European level in the field of aluminum profiles, which is the only aluminum alloy foundry in southern Italy, i.e., Metra Ragusa Spa and Ver.all Srl (belonging to the Industrial Group Metra). The chain also consists of several companies that handle the manufacture of accessories and com- ponents attached to the manufacture of aluminum frames. Closely linked horizontally are companies that manufacture accessories for windows and doors (hinges, handles, small metal parts, gaskets, etc.), machines for the machining of aluminum profiles, and insulating glass. Even this district is close to the model of metadistrict, particularly based on its multi-sectorial nature that is organized around a market leader.

The four industrial districts selected were born around the need to enhance the specificity of the local economic system in which they are inserted and are more than 'mature' structures, which indicates that it is possible to find stable relationships of interdependence between businesses and other entities intertwined with them in the districts as units of an entrepreneurial and local institutional structure that is willing to embark on a path of gradual growth into the model proposed. It consists of more than pilot projects in the construction of a meta-district; instead, it is a real recognition of these districts. Thus, only two of the four are recognized within the National Observatory of Italian Districts, i.e., the Mechanics and the Mechatronics Districts. It is absolutely strange that the District of Etna Valley is missing from the data of the National Observatory because even the ministry on the Catania District was repeatedly the recipient of both public resources and of analysis and evaluation.

A common critical issue to the district companies in Sicily is that they are often simply too small and are often micro-enterprises. Such dimensional problems are also generally related to the use of traditional technologies that are not particularly advanced, which thus leads to a weak propensity for innovation. The ability to build knowledge networks with research centers and universities, incubators of ideas, and science parks is vital in today's knowledge-based economy (Schilirò, 2010 a).

Furthermore, the model of Sicilian meta-districts, in particular, suffers because of the objective difficulties that occur at the system level, due to the many deficiencies in hard and soft infrastructure, inefficiencies in services, gaps and complicated rules in various bureaucracies, the weight of taxation, all of which promote submergence and opacity and can lead to "shadow alliances".

We are in the presence of a dynamic high diversification but with the following thing in common: there 


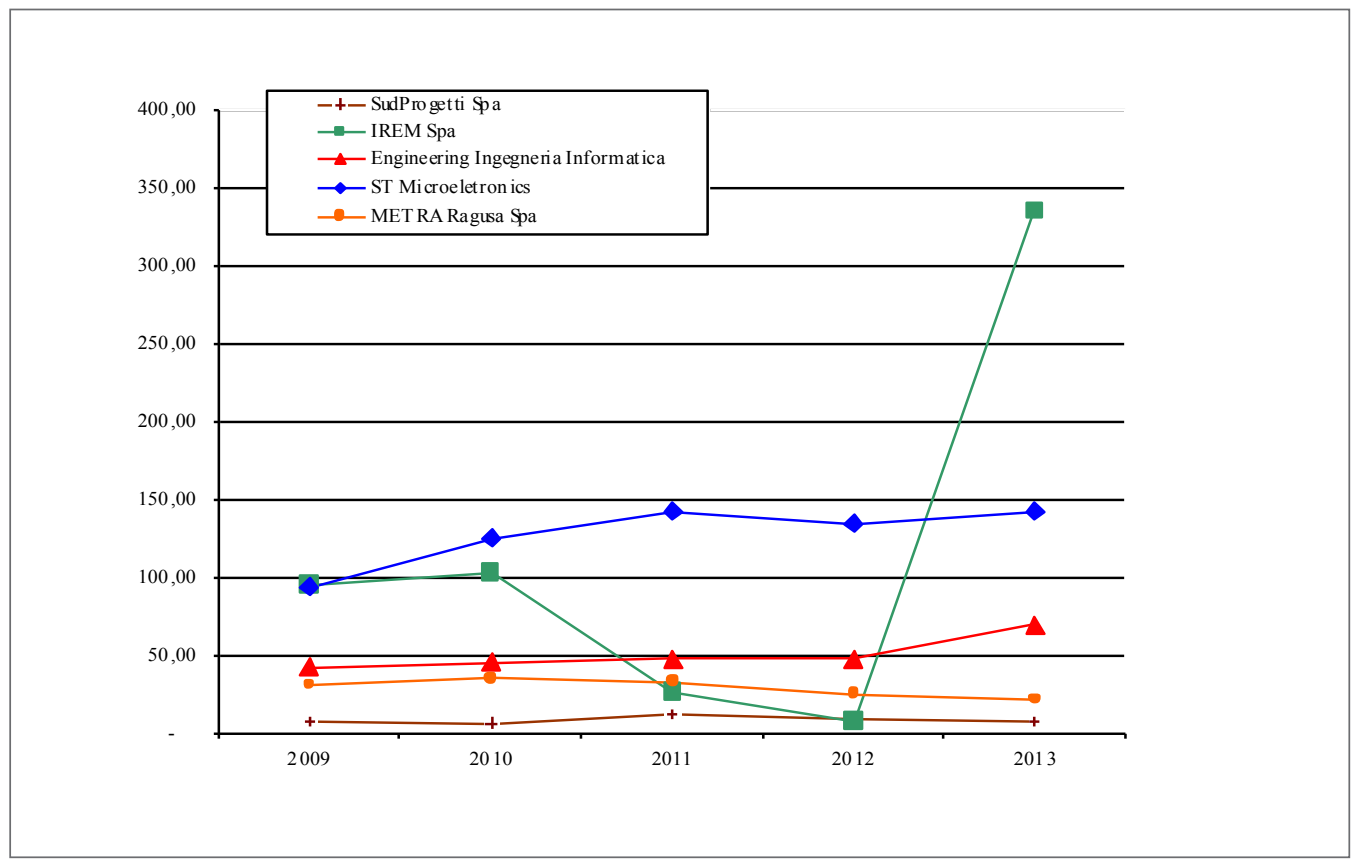

Figure 2. Evolution of revenues from turnover of the leading companies in the Sicilian Production Districts

is no "Sicilian model district" that consists of companies manufacturing products in small amounts and of poor quality for poor markets that are unbranded and that the crisis has greatly worn out over and over during the processes of globalization. Indeed, existing districts tend to differ sharply with regard to other companies outside the meta-districts not only in product endorsements and market but also in industrial organization, the degree of internationalization, the role of sub-contracting in other areas and many other key variables of their history and their current competitive positioning.

The availability of human resources is fundamental to the businesses in the productive districts, given the labor-intensive technologies in almost all the sectors studied. By contrast, the availability of local infrastructure, such as soil equipped for the production plants, is not typically readily available. Indeed, in many cases, there is evidence of enterprises that are newly born outside of areas equipped with adequate infrastructure and have instead used networks of long-haul transport.
The vast majority of districts are located in close proximity to major transport networks, mainly motorways.

With regard to the role of the decentralization of production, i.e., products made under subcontracts for companies in other areas, the experience of the four districts is varied. Again, the following different types of districts can be identified: those that arise due to the decentralization of production; those for whom decentralization is an important - but not the only element in their development; and finally, those for whom decentralization is of limited or no importance. For the Etna Valley district, decentralization is essential. No one ever imagined that high technology products could be produced there before a large company between Italy and France decided not to promote its own production investment in Sicily, creating the conditions for an economy of scale and a positive pole of attraction. The same conditions occurred for mechanics, thanks to productive investments in the petrochemical sector in Syracuse and Augusta. Production also freed the suppliers to establish themselves over the 
Table 6. Industrial districts in Sicily: number of employees

\begin{tabular}{|c|c|c|c|c|c|c|}
\hline & Distretto & 2009 & 2010 & 2011 & 2012 & 2013 \\
\hline \multicolumn{7}{|l|}{ Imprese/Occupati } \\
\hline SudProgetti Spa & Mechanics & 24 & 20 & 21 & 19 & 19 \\
\hline IREM Spa & Mechanics & 183 & 183 & 250 & 224 & 175 \\
\hline $\begin{array}{l}\text { Engineering Ingegneria } \\
\text { Informatica }\end{array}$ & Mechatronic & 3.597 & 3.812 & 3.928 & 4.065 & 6.077 \\
\hline ST Microeletronics & High Tech & 8.087 & 8.087 & 8.658 & 8.761 & 9.464 \\
\hline METRA Ragusa Spa & Aluminium & 147 & 131 & 129 & 111 & 110 \\
\hline
\end{tabular}

traditional relations of subcontracting. In these cases, the production and sub-contracted processing are not the elements that gives birth to the district; instead, they have contributed to the birth and beyond. The decentralization of production accompanies quantitative development, but it also happens to work with local entrepreneurs. Finally, there are the cases of Mechatronics Palermo or Aluminium, for which subcontracting was irrelevant.

Now, it is possible to reconstruct the dynamics of development and resilience for the different districts based on $t$ the scheme of interpretation. The values of turnover and employees refer to the 2009-2013 period to make an assessment over the years.

Analyzing data on revenue from the turnover of the five leading industrial districts (two for the machine building sector) (Fig. 2), we note that although there is some volatility registered over the years, at least for the IREM Spa, all enterprises do not suffer terribly or the same through the economic crisis, and some show significant resilience (in terms of turnover and employees) in their respective sectors.

These data seem to be confirmed in the general data on the Sicilian economy, which show that between 2001 and 2011, the proportion of manufacturing in the total number of employees was reduced from $11,4 \%$ to $9,2 \%$ (from $24,9 \%$ to $19,5 \%$ in Italy) while sectors in high-tech - and precisely those belonging to the productive districts - have increased their proportion of the total manufacturing sector (from $5,6 \%$ to $6,4 \%$ ), to a level that is higher than the national average (Bank of Italy, Regional economies, 2014).
As for employment, the trend of values is different, with some businesses increasing the number of employees significantly, whereas other companies resized with non-linear trends.

Compared to the regional data of a decrease in employment in the manufacturing sector of more than $10 \%$ over the 2009-2013 period, the employees of the leading Sicilian districts seem to respond better to the crisis with a resilience also relevant here. This resilience, although it appears significant in leading companies that feel the economic crisis but react to it, it is thinner than in the other member companies that show data less significant.

\section{Conclusions}

The study of the Sicilian productive districts - and particularly the industrial districts - suggests that the regional district system expresses a lack of capacity to react to the shocks generated by the recent economic crisis, which remains incompletely surmounted, except for the leading companies, which for their size, degree of innovation, openness to the outside, propensity to export, industrial relations and networking system, demonstrate that they otherwise hold up to the changes better. However, for these latter companies, values in revenues and employed seem to show a significant resilience to react to economic shocks and to recover along a path of development to pre-crisis values. It is, however, a fact that can help us to imagine effective paths to help the leading companies in regional manufacturing recover and reconstruct, including within the 
framework of a policy to revitalize the Italian and Sicilian manufacturing sector.

Following the crisis of recent years, companies in the industrial districts also shrank (the data must be considered net of the new district of aluminum), including in terms of the number of employees. However, even these data are to be read ambivalently. It is in fact likely that it is a natural process definition and re-definition of the boundaries and districts of the network system of the meta-districts with the exclusion of subjects that had been involved more for reasons of consistency and quality in the first phase.

It should be noted, also, that as the socio-economic dynamics of the four Sicilian industrial clusters are in many ways similar to those observed in other districts of the South of Italy, this study may involve an issue that is analogous to a difficulty that involves the entire Italian manufacturing system, regardless of its forms, regions and territories.

Ultimately, with regard to the objective of the research, which is to assess whether the productive districts recognized have a resilience to economic shocks and, therefore, may actually be a means of governance for the development of the territory, it should be noted that the results are not particularly comforting. Thus, the results illuminate (except for leading companies) a model of a cohesive, relatively internationalized company that makes some attempts at innovation.

In fact, the research found that the four districts examined are not yet sufficiently 'mature'; although they are well structured in terms of number of companies and number of employees - as required by the relevant regulations. Different causes and arguments might be developed in connection with this empirical evidence, but the main cause is the absence of strong economic and organizational relationships between companies within the manufacturing district. In addition, the lack of a significant regional industrial policy in favor of the productive districts not only refers to financial resources but also to overall policy support and articulated infrastructure, business services, taxation and bureaucracy, and human resources. This is, therefore, not so much about manufacturing districts, but instead (as discussed above) meta-districts or even business networks at present can form the basis for future regional and territorial development projects. Much remains to be undertaken both on the part of individual firms and public institu- tions to strengthen the entrepreneurial system and their degree of innovation and competitiveness on international markets, in addition to also developing the integration and cooperation processes.

\section{References}

Becattini, G. (1990). The Marshallian industrial district as a socio-economic notion. In F. Pyke, F. G. Becattini, \& W. Sengenberger (Eds.), Industrial districts and inter-firm cooperation in Italy (pp. 37-51). Geneva: International Institute for Labour Studies.

Bellandi, M., \& De Propris, L. (1982). A handbook of industrial districts. Cheltenham, UK: Edward Elgar Publishing Limited.

Berardi, M., \& Iannuzzi, M. (2012). Italian industrial districts: crisis or evolution? World Review of Entrepreneurship, Management and Sustainable Development, 8(1), 23-36.

Briguglio, L., Cordina, G., Farrugia, N., \& Vella, S. (2006). Conceptualizing and measuring economic resilience (Working Paper). Economics Department, University of Malta. Retrieved from https:// www.um.edu.mt/islands/publications_of_interest

Camuffo, A., \& Grandinetti, R. (2011). Italian industrial districts as cognitive systems: Are they still reproducible? Entrepreneurship and Regional Development, 23 (9-10), 815-852.

Christopherson, S., Michie, J. E., \& Tyler, P. (2010). Regional resilience: Theoretical and empirical perspectives. Cambridge Journal of Regions, Economy and Society, 3(1), 3-10.

Corò, G., \& Micelli, S. (2006). I nuovi distretti produttivi: innovazione, internazionalizzazione e competitività dei territory [The new production districts: innovation, internationalization and competitiveness of territories]. Venezia: Marsilio.

Cretì, A., \& Bettoni, G. (2001). Dai distretti ai metadistretti: una definizione [From the districts to the metadistricts: A definition]. Liuc Paper, 96, 1-17.

Dei Ottati, G. (1994). Cooperation and competition in the industrial district as an organization model. European Planning Studies, 2(4), 463-483.

Di Berardino, C., \& Mauro, G. (2011). Crescita economica e impatto della crisi: il ruolo dei distretti industriali in Italia [Economic growth and impact of the crisis: the role of industrial districts in Italy]. Economia e Società Regionale, 112 (1), 92-114. 
Foresti, G., Guelpa, F., \& Trenti, S. (2009). Effetto distretto: esiste ancora? [District effect still exists?]. Milano: Intesa Sanpaolo, Servizio Studi e Ricerch, Collana Ricerche.

Fortis, M., \& Quadrio Curzio, A. (a cura di), (2006). Industria e distretti. Un paradigma di perdurante competitività [Industry and districts. A paradigm of ongoing competitiveness], Bologna: Il Mulino.

Graziano, P. (2012). Rischio, vulnerabilità e resilienza territoriale [Risk, vulnerability and territorial resilience]. Quaderni del Dipartimento di Scienze Economiche e Sociali, Serie rossa: Economia, 87, 1-33.

Hassink, R., (2010). Regional resilience: A promising concept to explain differences in regional economic adaptability? Cambridge Journal of Regions, Economy and Society, 3(1), 45-58.

Marshall, A. (1972). Principles of Economics. London, UK: MacMillan.

National Observatory of Italian Districts. (2014). Report 2014. Roma: Unioncamere. Retrieved from http://www.osservatoriodistretti.org/rapporto2014-osservatorio-nazionale-distretti-italiani

Observatory Industrial Clusters and SMEs, Sicily. (2014). Assessorato delle attivita' produttive [Department Activities' Productive]. Retrieved from http://pti.regione.sicilia.it/portal/page/portal/ PIR_PORTALE/PIR_LaStrutturaRegionale/PIR_ AttivitaProduttive/PIR_DipAttivitaProduttive/ PIR_Distrettiproduttivi/PIR_Distrettiriconosciuti

Paniccia, I. (1998). One, a hundred, thousands of industrial districts. Organizational variety in local networks of small and medium-sized enterprises. Organization Studies, 19(4), 667-699.

Pendall, R., Foster, K. A., \& Cowell, M., (2007). Resilience and regions: building understanding of the metaphor (Working Paper No. 12). Macarthur Foundation Research Network on Building Resilient Regions, Institute for Urban and Regional Development, University of California.

Porter, M. (1998). Clusters and the New Economics of Competition. Harvard Business Review, 76 (6), 77-90.

Provasi, G. (2002). Lo sviluppo locale: una nuova frontiera per il non profit [Local development: A new frontier for the non-profit]., Milano: Franco Angeli.
Rullani, E. (2004). Economia della conoscenza. Creatività e valore nel capitalismo delle reti [Knowledge economy. Creativity and value in network capitalism]. Roma: Carocci.

Rullani, E. (2009). Lo sviluppo del territorio: l'evoluzione dei distretti industriali e il nuovo ruolo delle città, Economia Italiana [The development of the territory: The evolution of industrial districts and the new role of cities], Economia Italiana, 2, 427-472.

Schilirò, D. (2010a). I Distretti Produttivi in Sicilia. Analisi e proposte per la Competitività, Economia e Società Regionale [The Industrial Clusters in Sicily. Analysis and proposals for the Competitiveness]. Economia e Società Regionale, 3, 92-113.

Schilirò, D. (2010b). Distretti e quarto capitalismo [Districts and fourth capitalism], Franco Angeli, Milano.

Sforzi, F. (2003). The Tuscan model and recent trends. In G. Becattini, M. Bellandi, G. Dei Ottati, \& F. Sforzi (Eds.), From Industrial Districts to Local Development (pp. 29-61). Cheltenham: Edward Elgar.

Sforzi, F. (2009). The empirical relevance of industrial districts in Italy. In G. Becattini, M. Bellandi, L. De Propris (Eds.) A Handbook of Industrial Districts (pp. 327-342). Cheltenham: Edward Elgar.

Sheffi, Y. (2005). The Resilient Enterprise: Overcoming Vulnerability for Competitive Advantage. Cambridge, MA: Mit Press.

Signorini, F. L. (2000). Lo sviluppo locale: un'indagine della Banca d'Italia sui distretti industriali [Local development: a survey by the Bank of Italy on industrial districts]. Meridiana Libri, Corigliano Calabro.

Viesti, G. (2000). Come nascono i distretti industriali [How they are born the industrial districts]. BariRoma: Editori Laterza. 